\title{
Herders and hazards: covariate $d z u d$ risk and the cost of risk management strategies in a Mongolian subdistrict
}

\author{
Ariell Ahearn ${ }^{1}$ (D)
}

Received: 27 August 2017 / Accepted: 15 November 2017 / Published online: 13 December 2017

(C) The Author(s) 2017. This article is an open access publication

\begin{abstract}
Studies of mobile pastoralist livelihoods have shown that a variety of sociotechnical practices have been developed to achieve reliable outputs from livestock in variable arid and semi-arid environments. This paper builds upon the concept of pastoralists as high-reliability seekers rather than risk-averse and makes a case for understanding Mongolian herders as well adapted to livestock production in highly variable climatic conditions within a certain threshold of risk and uncertainty. This system fails, however, during instances of high uncertainty and covariate risk such as in cases of the natural hazard $d z u d$, which requires individual households to make significant cash investments in risk management. It forwards the idea that investing in local government-soum and bag leveladministrative capacity and infrastructure is needed to build system resilience to covariate risk. Based on ethnographic research in rural Bayankhongor, this paper interrogates how $d z u d$ interfaces with socio-economic factors amongst pastoralists in central west Mongolia.
\end{abstract}

Keywords Risk $\cdot$ High-reliability systems $\cdot$ Dzud $\cdot$ Mongolia $\cdot$ Pastoralism $\cdot$ Natural hazards

\section{Introduction}

It is said that there are two kinds of dzud. In the black dzud, there is no snow. There is no grass for livestock to graze. It is said that the black dzud is more difficult than the other one with snow. Dzud with snow has more than $25-30 \mathrm{~cm}$. Livestock cannot graze and it is even difficult to ride a horse. Such difficulties are called dzud. At the times of dzud herders should be well prepared with a good shed (to keep animals). This is often called khoroo. If a shed for livestock is very nicely warmed and enough

Ariell Ahearn

Ariell.ahearn-ligham@ouce.ox.ac.uk

1 School for Geography and the Environment, Green Templeton College, Oxford University, 43

Woodstock Road, Oxford OX26HG, UK 
fodder is prepared, then a herder can easily pass the dzud. It is pleasant for animals to be in the warm shed with some food. If not well prepared, and plus if the herder is not skilled and knowledgeable enough, then all of his livestock will die and will be left with no animals. No survival.

-Dawaa et al. (2012)

Livestock mortality is a part of pastoralist livelihoods around the world, where the challenging environmental and climatic conditions of the arid regions that pastoralists inhabit contribute to periodical livestock loss due to natural disaster events. Epidemics, droughts, dust storms, winds, hail and natural predators are some examples of risks faced by pastoralists discussed in the literature (Bollig and Göbel 1997). Fredrik Barth (1961: 102) described this phenomenon in his work with the Basseri pastoralists of Iran, "What is more, the capital asset itself, the flock, is, as we have seen, subject to unpredictable fluctuations and severe losses from natural causes, averaging as much as $50 \%$ in some disaster years". Barth's statement raises two issues that deserve close attention in understanding the nature of environmental hazards for mobile pastoralists. The first issue is the nature of variability in the arid environments where pastoralism is practiced. In non-disaster years, pasture conditions vary widely based on annual precipitation patterns and pastoralists have adapted their herding strategies to maximize benefit from this variability (Krätli 2017).

The second issue is the political economy of pastoralism, including the wider governance institutions and administrative systems that impact herder production strategies. The political economy includes everyday decision-making around grazing strategies, economic conditions, how resources are accessed and distributed, and who has rights to access and distribute these resources. Attention to the relationship between governance systems and household organization is needed to understand how risk is managed during extreme climatic hazard events. This article focuses on the political economy of the natural hazard, $d z u d$, in Mongolia and presents data based on qualitative research conducted at the subdistrict level in central Bayankhongor Province. In doing so, the paper builds upon the concept of pastoralists as high-reliability seekers rather than risk-averse. This article makes a case for understanding Mongolian herders as well adapted to livestock production in highly variable climatic conditions within a certain threshold of risk and uncertainty. This system can fail, however, during instances of high uncertainty and covariate risk such as in the cases of the natural hazard of $d z u d$. These uncertainties have taken new forms in the post-socialist context and the potential for increased climatic variability due to climate change. During dzud events, the cost of risk management is too high for many individual households to bear, especially during the cash-poor winter season in which $d z u d$ strikes. Covariate risk affects a large population at the same time (Vatsa and Krimgold 2000), compromising the effectiveness of mutual aid networks used to address more idiosyncratic risks. This article suggests that investing in rural infrastructure and the administrative capacity of soum and bag $^{1}$ level local government is needed to build pastoralist system resilience covariate risk.

A $d z u d$ is defined by environmental conditions which make natural pasture inaccessible to livestock. Dzud is categorized into six types (Fernandez-Gimenez et al. 2012; Middleton et al. 2015), and some of the more fatal $d z u d s$ have been slow onset and preceded by drought conditions (Tachiiri et al. 2008). Shinoda (2017) further refines scholarship on dzud using a climate memory model based on four disasters common in Eurasia: drought,

\footnotetext{
1 A soum is an administrative unit within a province, roughly equivalent to a county. A bag is the smallest administrative unit consisting of a subdistrict within the soum.
} 
dzud, dust storms and desertification (the 4Ds). This model identifies the interactions between the four disaster conditions and how they interact with livestock health, socio-economic conditions and human health. Non-disaster years, however, still present significant risks to herder households. The Mongolian climate is highly variable in terms of precipitation and temperature, with annual extremes moving between $40^{\circ}$ and $-50^{\circ}$ (Marin 2010; Sternberg 2008). Mongolian herder households have developed successful pastoralist productive systems in this highly variable physical environment.

Winter conditions in non- $d z u d$ years are characterized by challenging conditions including very low annual temperatures and changeable weather conditions. A study by Sternberg et al. (2009) has shown that in two sites in the South Gobi, during the severe $d z u d$ years from 1999 to 2002, the mean temperature in January was actually warmer than average temperatures over a longer time frame. Their study shows that warmer temperatures combined with an increase in winter precipitation may have created more cycles of freezing and thawing in the region which created $d z u d$ conditions characterized by inaccessible pasture. Winter temperature or drought conditions alone could not explain the disastrous effects of the $2000 d z u d$, and social factors were seen to play a role in the extent of disaster. Similarly, a failure of governance and disaster management has been seen to play a role in the severe livestock mortality of the $2010 \mathrm{dzud}$ (Sternberg 2010).

Similarly, Janes and Chuluundorj's (2015) nationwide survey from 2001 to 2003 concluded that the difference between $d z u d$ as a climate hazard and $d z u d$ as a disaster lies in socio-economic factors and forms of governance. These authors illustrate that herders are not only managing highly variable natural environments, but also produce in fluctuating economic conditions which increase vulnerability to natural hazards. Thus, this article builds upon the critique developed by Janes and Chuluundorj (2015) regarding lack of investment in the pastoral sector for covariate risk mitigation, "While hazards may not be modifiable by human agency, vulnerability is: disaster prevention hinges on the mitigation of those processes that produce it". In their view, vulnerability to natural hazards is a social phenomenon and can be addressed through human action at a variety of scales. My argument in this paper is that Mongolian pastoralists are reliability-seeking producers and have developed successful techniques for weathering the extreme winter conditions in non$d z u d$ years. During dzud years, the covariate nature of $d z u d$ risk causes a systemic failure, which encompasses broader political and economic infrastructures. The risk management strategies currently in place for $d z u d$ in Mongolia do not clearly differentiate between reliability-seeking and risk-averse herding strategies, or the systemic nature of $d z u d$ risk which requires interventions at an organizational rather than individual level. Currently, the types of risk management strategies required for $d z u d$ incurs multiple costs for cash- and labourstrained individual households. Remedies must consider broader investments in local government capacity which enable herders to access needed provisions in emergency situations and to ensure a more resilient rural economy. Thus, current research and development schemes focused on $d z u d$ resilience need to more clearly align the nature of $d z u d$ risk with ex-ante and ex-post risk management policies.

\section{Bayankhongor province}

This research is based on an ethnographic investigation of pastoralist work practices and household decision-making in Bayankhongor Province's Olziit, Gurvanbulag and Bayanbulag counties from 2012 to 2014. Seventy-five herder households were formally 


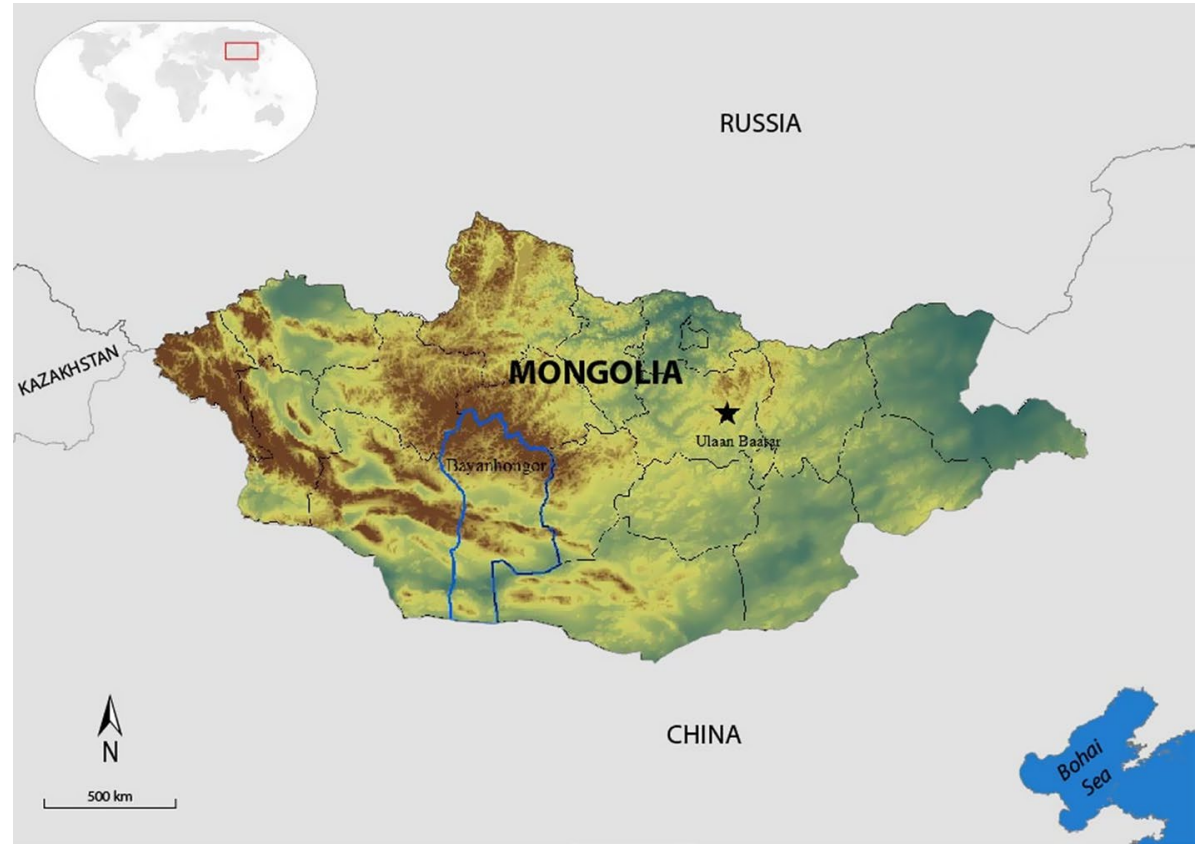

Fig. 1 Map of Mongolia with Bayankhongor Province highlighted

interviewed and countless informal interviews occurred alongside participant observation while living with households over the course of this time period. The author travelled extensively with an Olziit county bag governor in order to map the seasonal camp sites, water sources and mobility patterns of residents. Long-term fieldwork based on participant observation in combination with interviews and quantitative data analysis allowed for the collection of a suite of data which cannot be obtained through rapid assessment or onetime interviews with research participants. This range of data was analysed using MS Excel and Atlas Ti to identify behavioural themes amongst the households and factors that played a role in household organization, public administration and winter preparation (Fig. 1).

The central west province of Bayankhongor is amongst Mongolia's top five provinces with the greatest number of livestock and herders. Its geography includes the southern region of the Khangai mountain range, the eastern ridges of the Altai range and the Gobi Desert to the south (Atwood 2004, p. 39). In Bayankhongor, the total herd count for 2012 was 2,640,831 head of livestock, which is an aggregate of the "five snouts" represented by horses, yaks/cattle, camel, goats and sheep (National Statistical Yearbook 2013, p. 212). This number increased to $2,987,064$ in 2013 . Two major $d z u d$ or winter hazard events characterized by extreme cold, heavy snow and drought affected the livestock population in the 1999-2001 seasons as well as the 2009-2010 season, where around 700,000 head of livestock died in Bayankhongor and around 8.5 million livestock in the entire country (Fernandez-Gimenez et al. 2011). 


\section{Dzud, covariate risk and high-reliability systems}

As mentioned above, $d z u d$ refers to an extreme winter event, which leads to high livestock mortality and affects individual herder livelihoods as well as the Mongolian national economy and food supplies. It is defined as "deep snow, severe cold or other conditions that make forage inaccessible or unavailable and leads to high livestock mortality" (Fernandez-Gimenez et al. 2015). According to the World Bank (Benson 2011), a natural hazard becomes a disaster when the "event causes substantial damage, disruption and possible causalities, leaving affected communities unable to function normally without outside assistance" (p. 11). Recent research by Hahn (2017) on reports written on $d z u d$ by humanitarian agencies and international NGOs in Mongolia reveals that there are discrepancies in basic definitions and classifications of $d z u d$ types and when conditions are hazardous enough to declare an emergency. While $d z u d$ is classified as a climatic hazard, the extent of damage caused by a $d z u d$, household vulnerability to these damages and perceptions of $d z u d$ as a risk to livelihoods is variable and embedded in cultural, social, political and economic factors.

Research on risk amongst pastoralists highlights the combination of unpredictability and uncertainty which constitutes any given hazard event. If an event is perceived to be unpredictable and resulting in negative consequences, then it can be considered a risk. Bollig (2006) defines risk as "the culturally and socially embedded perceptions of future possible damage...They are multi-dimensional constructs and are linked (though perception) to the living conditions of a people (p. 10)". Likewise, individuals may perceive risk as coming from cosmological, environmental, political, economic or other factors which influence how individuals respond to a perceived risk. An issue of interest for the study of $d z u d$ is how the nature of risk has changed since the end of socialism and how herder costs of natural hazard risk management have increased in new political and economic contexts.

While individual households have adapted methods to produce reliably in highly variable climatic conditions, the pastoral system can be incapacitated during slow onset covariate risk situations such as $d z u d$. Covariate risk is distinguished from individual risks and is characterized by an event which affects all households in a certain region. A 2012 World Bank working paper highlights the effects of increasing climate variability due to climate change on covariate risk. The report states, "Climate change will exacerbate covariate risks (those affecting entire communities or countries), both direct (disaster; yield declines over large areas) and indirect (vector-borne epidemics; price and employment effects at the regional, national, and international levels)" (Kuriakose et al. 2012). In Mongolia, increasing variability of precipitation patterns and a trend of rising temperatures since 1940 potentially plays a role in the frequency and duration of $d z u d$. Currently, households in Mongolia are responsible for implementing their own natural hazard risk mitigation strategies and paying for the costs of damages. This decentralized system was introduced in the 1990s and has been heavily critiqued for its ineffectiveness in protecting herders from covariate $d z u d$ damages to herder households and the rural economy as a whole (Sneath 2003).

This can be seen in two severe $d z u d$ events since the end of socialism. For example, the severity of the 1999-2000 $d z u d$ event was exacerbated by the market economic reforms that had rapidly privatized the agricultural sector, brought many inexperienced new herders into pastoralism (Sneath 2003) and disabled the institutions which traditionally offered timely assistance for emergencies and bore the costs of disaster episodes. Rapid privatization of property in the collective, such as tractors and transport vehicles, occurred at the same time as a severe widespread economic crisis (Sneath 2003). Agricultural sector 
reform plans were not suited to the dire situation of the country at the time (Nixson et al. 2000), and many were forced into a subsistence mode of production with households bearing all the risks of pastoralist production. Immediate outcomes of the privatization process combined with economic crisis were significant problems with distribution and an increase in poverty and wealth inequality (Janes and Chuluundorj 2004; Janes et al. 2006; Nixson and Walters 2006; Rak and Janes 2004).

Additionally, rapid privatization combined with economic crisis changed the distributional frameworks that had supported state-led infrastructures for emergency relief and insurance against loss of herds during severe winters (Templer et al. 1993). In 1993, a year characterized by skyrocketing inflation and rural $d z u d$, Templer et al. (1993, p. 103) asked "The transition to the market economy raises the question of who is responsible for risk management: state or individual?" These scholars acknowledged that the breakdown of former centralized systems that developed ways to reduce uncertainty around covariate natural hazard $d z u d$ risks has led to a more vulnerable pastoralist economy. In the past, the Mongolian state responded to winter disasters with direct assistance such as delivering fodder by helicopter to households (Swift 2007). Similarly, a state Fodder Fund kept stockpiles of fodder in all provinces for easy distribution across the country. These mechanisms no longer function in a coordianted and systematic manner, and risk is now borne by individual households, incurring significant costs for livestock insurance, fodder and hay, transport and labour.

Within this discussion, there is a need to understand the way that pastoralists operate. A growing literature has illustrated that pastoralists inhabit arid and semi-arid environments characterized by non-equilibrium pasture conditions, where the location, quality and variety of vegetation fluctuate annually based on variations in rainfall (Middleton 2016). The non-equilibrium model takes into account the patchiness of arid environments, where the timing, amount and duration of precipitation can cause situations where drought and non-drought conditions might be only a few kilometres apart (Krätli 2017). In this context, reliability system theory postulates that highly variable environments without a steady state can be managed, not by introducing control, but by responding in kind with process variance in production (Roe 2013). In other words, variability in an environment can be managed with variability in practice in order to achieve stable output in production. In this model, variability is "a constitutive part of the ecosystem" (Krätli 2017, p. 142). Scholars who adopt the resilience systems framework for understanding pastoralism consider mobility, livestock husbandry choices that favour certain breeds and grazing habits, knowledge of landscape and opportunistic grazing to be examples of reliance-seeking rather than riskaverse practices (Roe et al. 1998a, b; Krätli and Schareika 2010).)

Regarding natural hazards such as drought, the high-reliability model predicts that pastoralists might combine risk-averse behaviours, such as moving away from droughtstricken areas, with reliability-seeking behaviours such as exploiting the "spatial and temporal diversity of the rangeland as a whole by using different areas in different ways so as to increase the chances of producing and maintaining peak herd sizes..." (Roe et al. 1998 b, p. 392). In the case of $d z u d$, where pasture becomes inaccessible due to ice, snow or extreme cold, herders employ different technologies and herding techniques to try to maintain livestock survival. At the same time, they engage activities to make livestock more robust to extreme winter weather by culling weak animals which are unlikely to survive harsh conditions, fattening livestock in autumn through otor grazing cycles, and creating secure and warm winter shelters (Murphy 2012). These reliability-seeking behaviours are combined with risk-averse measures during catastrophic or disastrous events. Recent work by Krätli (2017) reiterates that a natural drought characterized by low or no precipitation 
does not necessarily constitute a natural hazard for pastoralists. He writes, "While droughtas-scarcity-of-rains is a state of things outside human control (hence politically neutral), drought-as-inaccessibility-of- pasture can be affected by management and context: low precipitations triggering agricultural drought do not necessarily trigger pastoral drought, as long as the herders can access pasture elsewhere. Conversely, even without major differences in precipitations, pastoral drought can become more frequent as a consequence of reduced mobility" (p. 144). In the context of $d z u d$, which is also characterized by the inability of livestock to access pasture, what practices and forms of governance enable pastoralists to manage covariate environmental risks?

The literature from the social sciences on $d z u d$ in Mongolia focuses largely on household level strategies to manage risk, with a focus on migration, land tenure and the activities of local institutions, such as the creation of pasture user groups (Humphrey and Sneath 1996a, b; Fernandez-Gimenez et al. 2015). Research tends to focus on individual household behaviours to protect livestock during $d z u d$ rather than the activities of local government administrations or other non-herder participants. Research has not fully explained how herders themselves are members of local administrative units and the consequences of these political memberships for land tenure and mobility practices. A review of the recent literature indicates that the state is represented as "absent" and "insufficient" (Vindskog 2014 , p. 886) in responding to $d z u d$, or ineffective due to loss of funding and capacity since the transition to a market economy (Sternberg 2010). There is limited research on the activities of soum administration, and many studies pass over the roles of bag governors, veterinarians or environmental officers in reference to natural hazards. There is also limited discussion of the way administrative areas such as soum and bags are governed and the consequences of these frameworks on migration decisions and household organization. Thrift and Ichinkhorloo's (2015) work on mutual aid networks has identified a need to re-evaluate the concept of an independent household unit which is commonly taken for granted in the literature. This research points to the need to better understand the relationship between herders and local government, especially given the extensive work that local administrations do in terms of maintaining statistical databases on annual livestock gains and losses, managing winter and spring camp possession certificates, keeping track of the seasonal locations of herder households, maintaining wells, selling hay and fodder supplies, maintaining hay fields and participation in marketing of livestock products.

In the following sections, this paper will discuss the intersections between herder household organization and the engagement of public soum administrative staff in winter preparation and land management activities. These data illuminate the contradictions between the seasonal pastoralist economy, the annual investments needed to ensure against possible $d z u d$ risk and the role of local government in buffering natural hazard risks. Based on these findings, the paper will offer recommendations for changes in approaches to managing $d z u d$ risk.

\section{Natural hazard risk management costs}

Olziit is located approximately 20 kilometres from the provincial centre of Bayankhongor and is divided into six administrative subdistricts called bag. There were 189 households registered as herders in bag 1 in 2013. While some households move into neighbouring bag and sum, the majority of herders report seasonal movements within the bag between seasonal campsites. Many families in bag 1 use the same camp for winter and spring seasons, and there are a few families who do not move at all. The population of 
Table 1 Olziit households including number of camp sites, total livestock and time spent at winter camp

\begin{tabular}{|c|c|c|c|}
\hline Household ID & $\begin{array}{l}\text { No. of camp } \\
\text { sites }\end{array}$ & Total livestock & $\begin{array}{l}\text { Time at winter } \\
\text { camp (months) }\end{array}$ \\
\hline 1000 & 3 & 249 & 6 \\
\hline 1002 & 3 & 248 & 10 \\
\hline 1003 & 1 & 189 & 12 \\
\hline 1007 & 3 & 528 & 6 \\
\hline 1008 & 3 & 203 & 6 \\
\hline 1009 & 3 & 59 & $6-7$ \\
\hline 1010 & 3 & 458 & $6-7$ \\
\hline 1011 & 3 & 432 & $5-6$ \\
\hline 1015 & 3 & 542 & $6-7$ \\
\hline 1016 & 3 & 375 & $6-7$ \\
\hline 1017 & 3 & 72 & $5-6$ \\
\hline 1018 & 3 & 170 & 8 \\
\hline 1019 & 3 & 166 & 7 \\
\hline 1020 & 3 & 404 & $5-6$ \\
\hline 1021 & 3 & 310 & 6 \\
\hline 1023 & 3 & 224 & $6-7$ \\
\hline 1024 & 3 & 638 & 7 \\
\hline 1028 & 3 & 670 & $4-5$ \\
\hline 1030 & 3 & 320 & 4 \\
\hline 1032 & 2 & 470 & 5 \\
\hline 1033 & 3 & 336 & 5 \\
\hline 1034 & 3 & 85 & 6 \\
\hline 1035 & 3 & 273 & $7-8$ \\
\hline 1036 & 2 & 233 & 6 \\
\hline 1037 & 3 & 122 & 6 \\
\hline 1038 & 3 & 205 & 4 \\
\hline 1039 & 3 & 368 & 8 \\
\hline 1040 & 2 & 270 & 6 \\
\hline 1043 & 3 & 379 & 6 \\
\hline 1045 & 3 & 401 & $6-7$ \\
\hline 1060 & 1 & 138 & 5 \\
\hline 1061 & 1 & 47 & 5 \\
\hline 1062 & 1 & 80 & 12 \\
\hline
\end{tabular}

herder households interviewed in Olziit generally move between three primary seasonal camp sites. For the year November 2012-November 2013, most herders moved to their winter camp site (ovoljoo) between the months of October and November and remained at winter camps until cashmere season in March and April. Winter camp stay was on average 6 months, though some elderly, poor or disabled families remain in winter camp sites all year long. Table 1 offers more detail on the length of winter camp stay and the number of seasonal camps utilized. These results indicate that many families stay at winter camp locations for half the year or longer. 
Mobility patterns in 2013 contrast markedly from the negdel (collective) period, for which many herders worked prior to market reforms. At that time, the local administration determined mobility plans for the region. A herder named Tsevelma described the socialist system, "In the past, it was the time of command period (zakhirgaadaltiin uye). So those leaders or administrative people used to instruct herders to move to this and that places, right? Pass summer in that place, spend autumn in that place, winter in other place. It was the command period, so herders moved mainly in this way". During that time period, herders moved up to $200 \mathrm{~km}$ between summer and winter pastures. Now, long-distance movements are infrequent as herders stay within soum, and more often, bag boundaries. The following maps illustrate typical seasonal movements for three households. Each illustrates the importance of access to a water point in seasonal camp locations (Fig. 2).

Mobility patterns change according to environmental and social circumstances, but follow general trends in terms of seasonal camp sites and pasture usage. Age, presence of young children, elderly care, labour availability, water availability, and types of livestock and milking routines are examples of factors that influence migration decisions. Accessing school for children has also considerably influenced seasonal mobility decisions and household finance. A significant change since socialism has been the breakdown in statesponsored dormitories for school attending children. While dormitories still exist, many families do not want to send young children to soum centres alone as they perceive the conditions to be difficult and not conductive to studying. Thus, many families with schoolaged children split their households between the soum centre and the countryside pastures in order to access both schooling and maintain pastoralist livelihoods. In many cases, this leaves men (often alone) in the winter camp site to tend to livestock, while women spend the season in the centre, or moving back and forth between places if conditions permit (Ahearn and Bumochir 2016). Similarly, accessing resources such as banks, petrol, markets, government offices and medical care requires travel to centres.

Accessing school for children, as well as other resources, in centres puts labour strain on pastoralist households during the winter months and adds a significant financial burden. In addition to our own findings, a study by the NGO, People in Need (2017: 35), conducted in Sukhbaatar Province has shown that $95 \%$ of the surveyed population of herders had either a formal or informal loan which was spent largely on costs of education. This study found that between 14 and $30 \%$ of household annual expenditure was spent on education, compared to between 3 and 4\% on hay. Sneath's study (2012: 468) corroborates these findings, "Most take these [loans] out in late August and early September to pay for their children's school fees, the costs of repairing wells and producing animal fodder in winter. They aim to repay them in late April to June with the proceeds to cashmere and wool sales. The seasonal nature of market income, then, is one source of the need for loans". Research from Olziit indicates that many herders take out a new annual loan immediately after paying the former year's loan back with cashmere income. These findings illustrate that herders, especially households with fewer livestock who cannot easily liquidate livestock into cash, have a variety of high expenditures at a cash-poor time of year. Loans are used to cover expenses until income is generated in the spring. The striking element of this arrangement is that households are operating on loans or very tight budgets during the periods when $d z u d$ is most likely to occur. Further, expenditures on hay and fodder remain low compared to investments in education. This illustrates the vulnerability of cash-poor households during a $d z u d$ event when fodder availability may be inaccessible due to distance and supply, but households additionally face a cash shortage in being able to pay for fodder supplies and transport to pastures. Shortages in supplies of fodder in combination with transportation barriers 
(a)

a) Tsegee Family Ger Sites

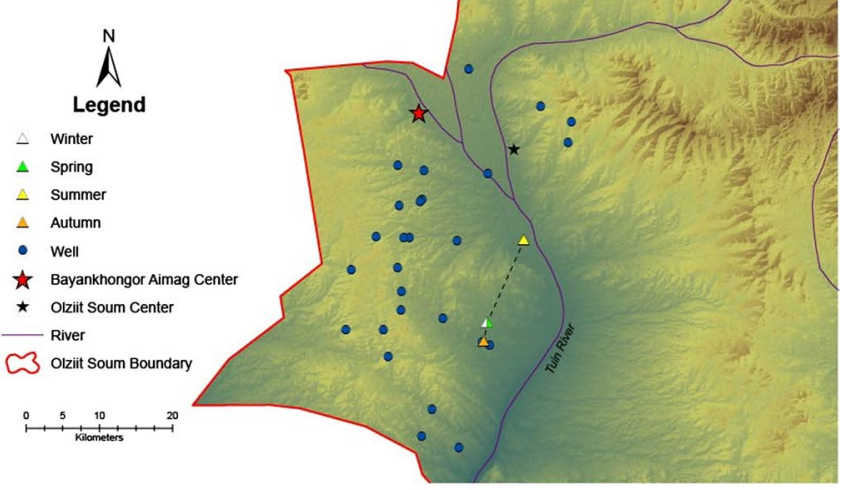

(b)

Purev Family Ger Sites

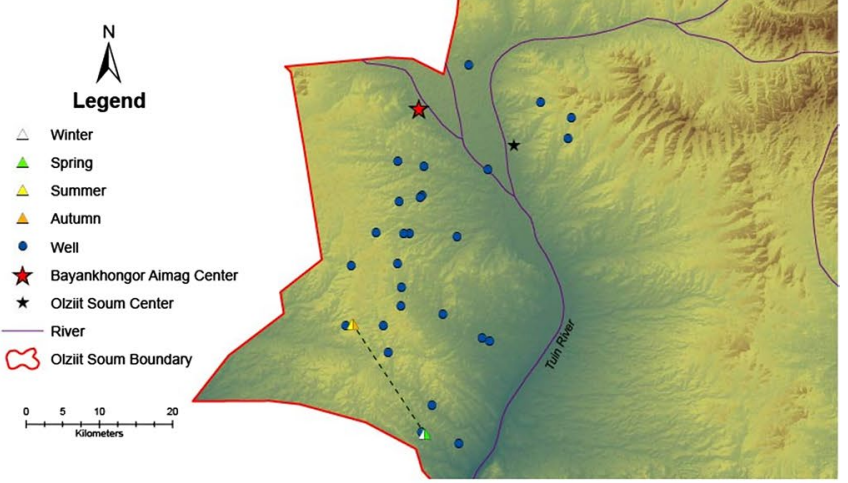

(c)

\section{Dorj Family Ger Sites}

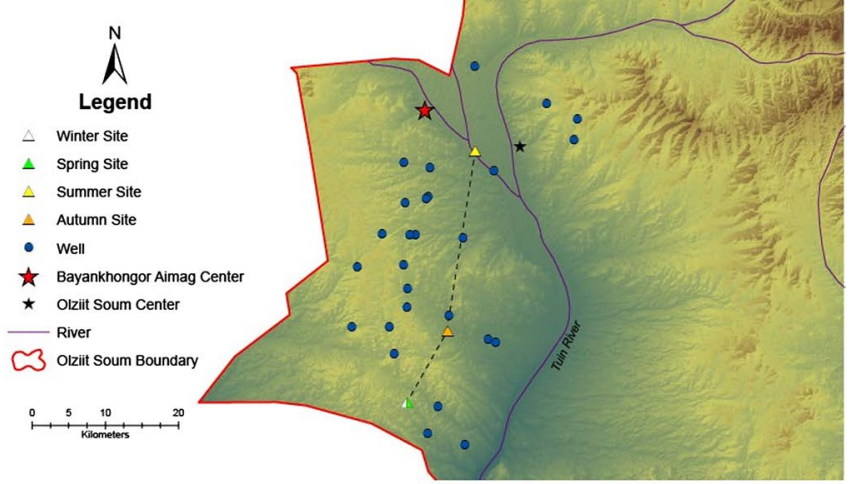

Fig. 2 Seasonal movements for Olziit households including well locations, 2013-2014. a Tsegee family seasonal camp sites. b Purev family seasonal camp sites. c Dorj family seasonal camp sites 
increase costs; Janes and Chuluundorj (2015: 92) report that the herders experiencing high livestock mortality purchased hay at more than double the price of households with low $d z u d$ livestock mortality.

Herders in Olziit speak about $d z u d$ as the most difficult risk they face in herding, naming other factors such as predator attack, disease, other types of foul weather and theft as other risks. All of the herders interviewed passed a $d z u d$ in the last 5-10 years, most notably the 2000-2001 and 2009-2010 dzuds. For households in Olziit, the late summer and fall months fall months are spent preparing for winter. Participant observation and interviews include the following winter preparation activities:

1. Conduct otor migrations by using a smaller ger to move more frequently to access available pasture.

2. Culling weak livestock in autumn.

3. Purchasing livestock insurance.

4. Stock khujir (saltlick) minerals and fuel in winter campsite.

5. Repair winter shelters.

6. Hay preparation and fodder purchasing.

Tsetsegmaa's family, which owns more than 900 livestock, said that today they make mobility decisions based on the availability of pasture and water "chasing the places with abundant grasses". This household identified the biggest risk to their herding livelihood as $d z u d$, particularly the events of 2000. At that time, Tsevelmaa's household had 460 animals. Due to the heavy snows, they were left with 207 livestock, but were able to recover to higher numbers by 2013. Many families with lower initial livestock numbers were not able to recover their livelihoods without significant cash investments, which has led many to leave herding altogether, fall into unmanageable debt or both (Sneath 2012). To prepare for winter, Tsevelmaa's family prepares hay and stores it for winter to feed until the spring. They also invest in veterinary care such as anti-parasite medications and other vaccinations which are additional costs.

Tomor and his wife, Pagma, another family from bag 1 in Olziit, prepared two vehicle loads of hay in 2012 for the winter and bought fodder made from wheat waste (heveg), and gave livestock vaccines and anti-parasite drugs. During the $2000 \mathrm{dzud}$, Pagma described the actions they took to protect their livestock. She explained, "We divided livestock into several flocks or groups. Then herd them as well as we can. We tried to herd the group in places where karagana [type of flowering plant] looked above snow or places with grasses. We just made our endless effort and herded livestock in the day time without proper food and sleep. At night, we had no food or sleep”. During the $d z u d$, this family herded livestock in three different groups. The weaker animals were kept in a shelter and fed hay by Pagma. The strongest animals were herded by her husband. Another group of livestock was herded in another pasture by their son.

Herders who passed $d z u d$ described the following actions taken to protect livestock:

1. Keep animals in a ger or corral for shelter and warmth.

2. Use draft animals for more agile movement across affected landscapes.

3. Feed animals fodder and hay.

4. Herd livestock in separate groups depending on age and health.

5. Split up livestock herd and distribute to other families, sometimes to other soum. 
Pastoralist work practices, and by extension experiences of $d z u d$, cannot be treated as a purely rural phenomenon in isolation from other social processes and efforts to access cultural and economic resources. The financial costs of managing $d z u d$ risk are currently the responsibility of individual households, and the importance of securing adequate shelter and fodder for livestock during $d z u d$ is a recurring theme in interviews with herders. The $2000 d z u d$ in Olziit provides evidence of this point. Another family which passed the 2000 $d z u d$ described, "In this $d z u d$, large livestock were buried to death under snow. Mainly we did not have anything to feed. We did not even bring all of the large livestock that were at pasture to our shelter. Those livestock had gone for grazing on their own and disappeared and died. We used to have 30 horses and were left with nothing...Snow was piled and there were no vehicles or transportation. We kept feeding the sheep, goats and cattle that were in the shelter. We just brought grasses and wheat waste fodder".

These vignettes are emblematic of the experiences of herders who faced $d z u d$ conditions and bring to light the constraints faced by households to respond to natural hazard risks. The herders interviewed all experienced damages to their livestock herd, but continue with pastoralist livelihoods in the Olziit region. Their experiences passing $d z u d$ expose the importance of access to cash, fodder and labour during times of the year when both are in short supply. Further, the covariate nature of $d z u d$ puts additional pressure on existing pasture reserves and supplies in soum centres, which can increase the cost of these resources at critical times. Traditional mutual help networks are also constrained during covariate natural hazard events, as households all struggle to contain damage to their livestock, leaving little time to assist others (see also Vatsa and Krimgold 2000). The following section focuses on the role of local government in the pastoralist economy and household winter preparations in order to elucidate the role of soum governments in $d z u d$ risk management.

\section{Soum and bag level administration}

Local government administrations are the primary agents of state-led environmental governance and supervise biannual livestock counts, the formalization of winter camp possession for households, and monitor wells, pasture use and environmental conditions. Established family networks and wealthy herders, however, also play an influential role in land use patterns and the establishment of user rights to pasture resources on the ground (Ahearn 2016; Murphy 2014). The intersection of formal government regulations and traditional custodial use-based land tenure practices form the basis of territorial rights in rural Bayankhongor today. Within this context, Fernandez-Gimenez et al. (2012) acknowledge the varied preparation and response to the 2009-2010 dzud by soum governments in Arkhangai and Bayankhongor provinces. In these cases, successful local government actions included negotiations to facilitate pasture access across soum boundaries and active mitigation of 'hoofed $d z u d$ ' Fernandez-Gimenez et al. (2012) which involves the migration of households and their livestock into the grazing areas of neighbouring soums. For example, "In Bayantsagan, the soum government actively encouraged herders to prepare well for winter, facilitated fall sale of livestock, negotiated otor agreements in advance of winter to send 77 Bayantsagaan households and 40,000 head of stock to other soum in 3 aimags, and effectively coordinated emergency aid during the $d z u d$ (p. 843)". Middleton et al. (2015) also acknowledge the role of some individual local government actors in facilitating long-distance migration and the early distribution of fodder and other forms of assistance. These articles both illustrate the uneven leadership and capacity of soum administrations 
in addressing slow onset $d z u d$. Some cases demonstrate an effective centralized response while others provide evidence of institutionally weak capacity.

Evidence from Olziit also suggests that soum governments and administrators such as bag governors and environmental officers are highly involved with herder households registered in their territorial jurisdiction. A bag governor in Olziit, for example, has worked in this position for over 10 years and visits households once a month, sometimes more, driving long distances for days at a time in his personal vehicle, a Hyundai Excel. He communicates frequently with herders via cell phone, through home visits and during bag and soum meetings, and is familiar with the socio-economic situation of all households registered within the bag. I accompanied him on his rounds over the course of 2012-2013. In June and July 2012, he drove to each herder's home to buy sheep wool as part of a soum government initiative and visited households with two environmental officers. He also pressed herders to buy livestock insurance, reminding households of the 1 July deadline during home visits and collected money to sign them up to the index-based scheme (see Mahul and Skees 2007 for more on index-based livestock insurance). In one case, he gave a family a loan to purchase insurance before the deadline passed.

Again, in October 2013, the bag governor, the bag doctor and a soum government livestock specialist visited herder homes to facilitate winter preparation activities. During a home visit, the livestock specialist explained to herders that Bayankhongor aimag initiated a scheme to reduce the number of livestock throughout the aimag because the Ministry of Industry and Agriculture forecasted the upcoming winter weather to be potentially hazardous. The government initiative facilitated livestock sales of goats, sheep and cattle to a meat reserve company in exchange for hay and fodder provision by the company. The herders could also choose if they only wanted to sell animals in exchange for cash, or if they wanted to buy fodder and hay for cash rather than participate in the exchange. The initiative offered to buy lambs for 70,000T, a 2-year-old sheep for 100,000T and a mature male sheep for 130,000T. A pressed block of hay was offered at 7500T and wheat waste fodder for 6500T. These arrangements were made directly with households during administrative home visits. Such visits are common throughout Olziit, and bag governors track the location of herder camp sites with particular attention to winter camps.

Each soum in Mongolia has different regulations regarding camp possession rights and regulations around pasture. For example, in Olziit a household can have possession rights over only one winter camp, which must be at a distance of $2 \mathrm{~km}$ from other household winter camps (Ahearn 2016). In Omnogovi Province's Khanbogd soum, on the other hand, some households have multiple winter camp possession certificates and thus are able to control a larger territory of pasture and water points. These decisions are locally made and have consequences for migration decisions during periods of acute drought or $d z u d$. A herder in northern Bayankhongor's Gurvanbulag county, for example, related that they moved outside of their soum boundaries due to early snowfalls in September and October, "we moved to the Khangai. There, in the land of others, people chase you out sometimes, they do not want to share their pasture land, unless the local government makes a decision. Because every place is possessed by somebody". These dynamics indicate that the potential damages of a covariate natural hazard such as $d z u d$, which poses a significant risk of livestock loss to households regardless of wealth differentials (Middleton et al. 2015), are exacerbated or buffered by the management capability of county-level governance institutions. In these cases, a system of storage for hay and fodder resources and availability of warm shelters would reduce the pressure of herders to move into neighbouring soums which create "hoofed $d z u d$ " conditions. Likewise, creating corridors across larger geographical areas for herders to move into during $d z u d$ conditions can help to overcome the 
fragmentation of land use strategies. The current political economy of pastoralism in Mongolia is based on household possession of winter camp sites and localizes grazing in these territorial configurations. While this land tenure policy may create a sense of security, it also does not accommodate longer migrations across soum boundaries which have been identified as a strategy to decrease livestock mortality during $d z u d$.

Finally, another issue to consider is the centralization of resources in provincial centres and how this impacts access to information, supplies and support for more remote herders. With lack of resources in remote areas, achieving proximity to provincial centres appears to be a way that herders seek protection from potential $d z u d$ in addition to other reasons. Olziit, which at its closest boundary is $20 \mathrm{~km}$ from the provincial centre, has seen an influx of herder households from southern Bayankhongor in the last decade. The bag governor related, "In our case, the number of herders are increasing. When I received the position of bag governor, there were only 87 or 88 herder households. Since that time, now it has reached 200 herder households. However, it is not actual growth. It is a kind of artificial growth. Our soum is closer to Bayankhongor aimag. That's why herders from Bogd, Bayangovi and other sums transfer their administrative registration to our soum in large numbers. Otherwise, herders who are originated from this place and lived for generations in this soum are very few".

From extensive grounded research in Olziit, we can observe an active soum government with close relations to herders registered in each bag. These relationships are localized, and leadership at a provincial level is required for communication and coordination across soum boundaries. Covariate risk management requires this level of broad institutional management to overcome the prohibitive costs of $d z u d$ preparation for individual households. While many $d z u d$ researchers portray an absent state in rural areas, the findings of this paper show that the local government at least in the Olziit county region is active and engaged though administrators such as bag governors and environmental officers. These already existing frameworks can be positively enhanced to reduce the damages caused by dzud.

\section{Discussion and conclusion}

Most herders actively engaged in the pastoralist economy in Mongolia today have had an experience of $d z u d$ in their lifetime. This article advocates for understanding herders as primarily reliability-seeking producers rather than risk-averse and illustrates that herders successfully navigate the extremely variable environment of Mongolia's climate in non- $d z u d$ years. More than two decades of research has illustrated the consequences of post-socialist economic crisis, decentralization, structural adjustment and market-based reforms on the pastoral rural economy. New forms of land tenure have been established, such as winter and spring camp possession rights. The nature of dzud as a natural hazard has shifted alongside this changing political economy. Covariate risks are now the responsibility of the individual herder household to manage - a major shift away from the past role of centralized institutions which enabled longer range migrations and provided an extensive infrastructure for $d z u d$ preparation and response.

As this article has shown, household experiences of damage and loss due to $d z u d$ vary and influence how households choose to manage risk in the future. Across the board, herders state that provision of hay and fodder, warm shelters and moving herds to areas which have natural pasture available are strategies to protect livestock and decrease livestock 
mortality. While these strategies may appear to be straightforward, a major obstacle is the prohibitive costs of risk management for many households which are burdened with both formal and informal loans. The growing role of debt in the pastoral economy should be accounted for in the exposure of herders to natural hazard risks. As the People in Need (2017) report states, approximately $50 \%$ of herders in the regions with the highest livestock mortality rates during $d z u d$ own 200 livestock or less. Low herd numbers mean that these households potentially face livelihood loss due to $d z u d$. Additionally, household finances are devoted to investments in education, which additionally strains cash-poor households during $d z u d$-prone seasons. At the heart of risk management for $d z u d$ is the need to find low-cost solutions for families which have little bandwidth to make investments of this kind.

At the same time, these broader socio-economic factors interact with complex environmental systems which, as Shindoa (2017) explains, has long-term environmental memories of a disaster complex including drought, dust storms and desertification. The increasing variability in precipitation patterns along with rising temperatures due to climate change complicates production decisions around when and where to move, sell animals or comb cashmere. Combined with a fluctuating market for raw materials such as cashmere, wool, meat, hides and dairy products, herders manage a high degree of uncertainty even outside of $d z u d$ years. The findings from this paper suggest that perhaps a fifth " $\mathrm{D}$ ", which sums up a natural hazard disaster equivalent in today's political economy, can be added to the 4D framework: Debt.

While household organization and labour are presented as an important element in adaptation to $d z u d$ in the literature, there is little in-depth discussion of herder everyday decision-making and constraints, as well as household aspirations beyond herding, and relationships and mobility beyond pastures. The environmental determinism that underlies many discussions of $d z u d$ and natural resource management in Mongolia needs to engage with the bigger picture of how pastoralism as a form of work is changing in response to broader economic and social changes. For example, accessing school in settlements for children affects labour availability during the winter and spring seasons. These are periods of time when livestock are at high risk from $d z u d$ conditions.

As experts in managing uncertainty, herders should be consulted to develop future policies to manage $d z u d$ risk in Mongolia. This paper has indicated that covariate risks require greater investment in local governments to improve capacity to reduce uncertainty and lower the costs of risk management for individual herder households. Soum governments might coordinate their work to establish emergency migration corridors across soum boundaries, provide information to herders around where accessible pasture is located, and build infrastructure for fodder storage and emergency shelters. International organizations might consider examining the supply chain for hay and fodder in rural Mongolia and develop policies to reduce costs for these supplies. Finally, political will is needed to ensure that greater investments are made in the rural economy in order to protect pastoralist households from environmental and economic shocks and therefore make Mongolia as a whole more resilient.

Acknowledgements Funding was provided by Economic and Social Research Council. The author is grateful for the reviewers' comments which greatly improved this paper.

Open Access This article is distributed under the terms of the Creative Commons Attribution 4.0 International License (http://creativecommons.org/licenses/by/4.0/), which permits unrestricted use, distribution, and reproduction in any medium, provided you give appropriate credit to the original author(s) and the source, provide a link to the Creative Commons license, and indicate if changes were made. 


\section{References}

Ahearn A (2016) The role of kinship in negotiating territorial rights: exploring claims for winter pasture ownership in Mongolia. Inner Asia 18:245-264

Ahearn A, Bumochir D (2016) Contradictions in schooling children among Mongolian pastoralists. Hum Org 75(1):87-96

Atwood CP (2004) Encyclopedia of Mongolia and the Mongolian empire. Facts on File, New York

Barth F (1961) Nomads of South Persia: The basseri tribe of the khamseh confederacy. Little, Brown, Boston

Benson C (2011) Dzud disaster financing and response in Mongolia. The World Bank, Washington

Bollig M (2006) Risk management in a hazardous environment: a comparative study of two pastoral societies. Springer, Berlin

Bollig M, Göbel B (1997) Risk, uncertainty and pastoralism: an introduction. Nomadic Peoples 1(1):5-21

Fernandez-Gimenez M, Batbuyan B, Batkhishig B (2011) Understanding resilience in mongolian pastoral socio-ecological systems: adapting to disaster before, during, and after the 2010 dzud-year 1 report. Report no. 70217. World Bank, Washington, DC. https://openknowledge.worldbank.org/bitstream/han dle/10986/12758/702170ESW0P1200dez000June021002011.pdf?sequence $=1$. Accessed 28 Sept 2015

Fernandez-Gimenez ME, Batkhishig B, Batbuyan B (2012) Cross-boundary and cross-level dynamics increase vulnerability to severe winter disasters (dzud) in Mongolia. Glob Environ Change 22:836-851

Fernandez-Gimenez ME, Batkhishig B, Batbuyan B, Ulambayar T (2015) Lessons from the dzud: community-based rangeland management increases the adaptive capacity of Mongolian herders to winter disasters. World Dev 68:48-65

Hahn A (2017) Complexity of Mongolian stakeholders' dzud preparation and response. Nat Hazards. https:// doi.org/10.1007/s11069-017-2907-2

Humphrey C, Sneath D (eds) (1996a) Culture and environment in inner Asia, Vol 1. The pastoral economy and the environment. The White Horse Press, Cambridge

Humphrey C, Sneath D (eds) (1996b) Culture and environment in inner Asia, Vol 2. Society and culture. The White Horse Press, Cambridge

Janes CR, Chuluundorj O (2004) Free markets and dead mothers: the social ecology of maternal mortality in post-socialist Mongolia. Med Anthropol Q 18(2):230-257

Janes C, Chuluundorj O (2015) Making disasters: climate change, neoliberal governance and livelihood insecurity on the Mongolian steppe. School for Advanced Research Press, Sante Fe

Janes CR, Chuluundorj O, Hilliard CE, Rak K, Janchiv K (2006) Poor medicine for poor people? Assessing the impact of neoliberal reform on health care equity in a post-socialist context. Glob Public Health $1(1): 5-30$

Krätli S (2017) Comment 1: pastoral localization of humanitarian aid. The need to re-qualify the pastoral context. Afr Study Monogr Suppl Issue 53:141-146

Krätli S, Schareika N (2010) Living off uncertainty: the intelligent animal production of dryland pastoralists. Eur J Dev Res 22:605-622

Kuriakose AT, Heltberg R, Wisemen W, Costella C, Cipryk R, Cornelius S (2012) Climate responsive social protection. Social protection and strategy, Discussion paper no. 2010. World Bank

Mahul O, Skees J (2007) Managing agricultural risk at the country level: the case of index-based livestock insurance in Mongolia. The World Bank, Policy research working paper 4325

Marin A (2010) Riders under storms: contributions of nomadic herders' observations to analysing climate change in Mongolia. Glob Environ Change 20(1):192-207

Middleton N (2016) Rangeland management and climatic hazards in drylands: dust storms, desertification and the overgrazing debate. Nat Hazards. https://doi.org/10.1007/s11069-016-2592-6

Middleton N, Rueff H, Sternberg T, Batbuyan B, Thomas D (2015) Explaning spatial variations in climate hazard impacts in western Mongolia. Landsc Ecol 30:91-107

Murphy DJ (2012) Encountering the franchise state: dzud, otor and transformations in pastoral risk. In: Knauft B, Taupier R (eds) Mongolians after socialism: politics, economy, religion. Admon Press, Ulaanbaatar, p 67

Murphy DJ (2014) Ecology of rule: territorial assemblages and environmental governance in rural Mongolia. Anthropol Q 83(3):759-792

National Statistical Office of Mongolia (2013) National Statistical Yearbook: 2012. Ulaanbaatar. http:// www.1212.mn/en/. Accessed 29 Sept 2015

Nixson F, Suvd B, Luvsandorj P, Walters B (eds) (2000) The mongolian economy: a manual of applied economics for a country in transition. Edward Elgar Publishing Limited, Cheltenham, UK

Nixson F, Walters B (2006) Privatization, income distribution, and poverty: the Mongolian experience. World Dev 34(9):1557-1579 
People in Need (2017) Indebtedness and its link to vulnerability during dzud episodes amongst vulnerable households. https://www.clovekvtisni.cz/uploads/file/1485342111-Indebtedness_Dzud.pdf. Accessed 15 Aug 2017

Rak K, Janes CR (2004) Reproductive health in post-transition Mongolia: global discourses and local realities. Perspect Glob Dev Technol 3(1/2):171-196

Roe E (2013) Making the most of mess. Reliability and policy in today's management challenges. Duke University Press, Durham

Roe E, Huntsinger L, Labnow K (1998a) High reliability pastoralism. J Arid Environ 39:39-55

Roe E, Huntsinger L, Labnow K (1998b) High-reliability pastoralism vs risk-averse pastoralism. J Environ Dev 7(4):387-421

Shinoda M (2017) Evolving a multi-hazard focused approach for arid Eurasia. In Sternberg T (ed) Climate hazard crises in Asian societies and environments. Routledge, Oxon, pp 73-102

Sneath D (2003) Land use, the environment and development in post-socialist Mongolia. Oxf Dev Stud 31(4):441-458

Sneath D (2012) The 'age of the market' and the regime of debt: the role of credit in the transformation of pastoral Mongolia. Soc Anthropol 20(4):458-473

Sternberg T (2008) Environmental challenges in Mongolia's dryland pastoral landscape. J Arid Environ 72(7):1294-1304

Sternberg T (2010) Unraveling Mongolia's extreme winter disaster of 2010. Nomadic Peoples 14(1):72-86

Sternberg T, Middleton N, Thomas D (2009) Pressurized pastoralism in south Gobi province, Mongolia: what is the role of drought? Trans Brit Geogr 34:364-377

Swift JJ (2007) Institutionalizing pastoral risk management in mongolia: lessons learned. FAO case study

Tachiiri K, Shinota M, Klinkenberg B, Morinaga Y (2008) Assessing Mongolian snow disaster risk using livestock and satellite data. J Arid Environ 72:2251-2263

Templer G, Swift J, Payne P (1993) The changing significance of risk in themongolian pastoral economy. Nomadic Peoples 33:105-122

Thrift E, Ichinkhorloo B (2015) Management of dzud risk in Mongolia: mutual aid and institutional interventions. In: Proceedings of the trans-disciplinary research conference: building resilience of Mongolian rangelands, Ulaanbaatar Mongolia, June 9-10, 2015

Vatsa SK, Krimgold F (2000) Financing disaster mitigation for the poor. In: Kreimer A, Arnold M (eds) Managing disaster risk in emerging economies. Disaster risk management series no. 2. The World Bank, Washington

Vindskog BV (2014) Natural calamities and 'the Big Migration': challenges to the Mongolian health system in 'the Age of the Market'. Glob Public Health 9(8):880-893 